УДК 378.141:004.8

DOI: 10.15587/2313-8416.2015.36409

\title{
ІНСТРУМЕНТИ ШТУЧНОГО ІНТЕЛЕКТУ У РУСЛІ ПРОБЛЕМАТИКИ ПЕДАГОГІЧНОЇ ДІАГНОСТИКИ
}

\author{
(C) Л. Е. Гризун \\ В роботі висвітлено сутність, функиії та основні проблеми педагогічної діагностики. На основі їх аналізу \\ виокремлено напрями штучного інтелекту, які мають певний потенціал щуодо розв'язання нагальних за- \\ вдань педагогічної діагностики. Схарактеризовано дидактичне забезпечення фахової підготовки студентів \\ педагогічних спеціальностей до застосування інструментів штучного інтелекту для розв'язання завдань \\ педагогічної діагностики
}

Ключові слова: педагогічна діагностика, фахова підготовка студентів; моделі представлення знань, нечітка логіка, кластерний аналіз

The paper covers essence, functions and main problems of pedagogical diagnostics. Basing on their analysis there were distinguished branches of artificial intelligence which have certain potential as for solution of current tasks of pedagogical diagnostics. Necessary didactic facilities of professional training of students of pedagogical majors as for applying of AI tools to the problems of pedagogical diagnostics are characterized

Keywords: pedagogical diagnostics, students' training, knowledge representation models, fuzzy logic, cluster analysis

\section{1. Вступ}

Сучасні завдання підвищення якості освіти на всіх іiї рівнях та удосконалення професійної підготовки сучасного фахівця будь-якого профілю актуалізують розвиток педагогічної діагностики як прикладного напряму педагогіки. Зрозуміло, що в умовах інформатизації суспільства особливого значення набуває залучення потужних засобів та наробок різних галузей інформатики та прикладної математики до розв'язання нагальних завдань педагогічної діагностики, а також удосконалення професійної підготовки педагогічних працівників у руслі цих завдань.

\section{2. Постановка проблеми}

Дослідники, які працюють у цій галузі відзначають, що головною метою педагогічної діагностики $є$ інформаційне забезпечення системи управління навчальним процесом, вибір оптимального методу навчання у конкретний його момент, що передбачає розробку методів всебічного вивчення результативності навчально-виховного процесу, забезпечення його валідності, надійності та достовірності.

Для досягнення своєї мети педагогічна діагностика має відповідати певним вимогам, виокремленню яких присвячено низку досліджень. Спираючись, зокрема, на працю [1], наведемо декілька найголовніших вимог до здійснення педагогічної діагностики:

- об'єктивність; поєднання педагогічної діагностики із самоконтролем [2, 3];

- систематичність [2, 3], що дозволяє вивчати динаміку навчальних досягнень і розвитку особистості студента, забезпечує оперативність формування рекомендацій за результатами діагностики, привчає студента до грамотного планування власної навчальної діяльності;

- гласність, що передбачає повідомлення діагностичних даних та результатів їх інтерпретації самому студенту, пояснення принципів аналізу даних і обгрунтування рекомендацій;
- етичність; комплексне застосування методів дослідження [2, 3], що забезпечує підвищення інформативності діагностики, зменшує вплив похибки окремих методів на кінцевий результат;

- індивідуальний підхід до діагностики кожного студента, що передбачає дослідження результатів роботи кожного учня, його особистісної навчальної діяльності, а також індивідуальний вибір методів діагностики і застосування адаптивних алгоритмів діагностичних процедур тощо.

Впровадження у навчальний процес інформаційно-комп'ютерних технологій спонукало розробку і впровадження все більш досконалих педагогічних програмних засобів, що вимагає додержання спеціальних вимог до комп'ютерно-оріснтованих систем діагностики, зокрема тестової. Серед них виділяють такі вимоги, як:

- використання декількох форм завдань;

- можливість вибору завдання випадковим чином 3 наявної сукупності тестових завдань;

- відображення варіантів відповіді у випадковому порядку;

- збереження результатів тестування, в тому числі усіх відповідей учня (студента); можливість проведення аналізу тестових завдань, всього тесту, відповідей кожного учня, можливість експорту результатів тестування в інші програмні засоби для більш детального їх аналізу [4].

Комп'ютерно-орієнтовані системи педагогічної діагностики мають забезпечувати:

- реалізацію механізму зворотного зв'язку у системі управління навчальною діяльністю;

- порівняння досягнутих результатів з їх ідеалізованою моделлю, побудованою у відповідності до нормативних вимог;

- побудову прогнозу;

- поєднання навчальної, виховної, розвивальної, мотиваційно-стимулючої та інших функцій.

Наведені вище вимоги до педагогічної діагностики та їі систем актуалізують підвищення рівня розвитку науково обгрунтованої методології педагогічної 
діагностики; удосконалення організації процесу діагностування, що включає технологію і методики вимірювання та відповідний аналіз їх результатів; забезпечення спеціальної підготовки спеціалістів до розробки систем педагогічного діагностування тощо.

Як зазначалося вище, проблеми педагогічної діагностики вивчаються багатьма вченими. Проте, незважаючи на значні досягнення дослідників у цій галузі, слід відмітити наявність проблем, що виникають як у процесі діагностування, так і при інтерпретації його результатів. Зокрема, залишається актуальним проведення якісного аналізу предметної області з метою іï структуризації та виявлення системи знань, які мають бути сформовані у тих, хто навчається, в результаті вивчення предметної області (фактично навчальної дисципліни) та, відповідно, продіагностовані щодо їх сформованості. Очевидно, що такий аналіз навчальних дисциплін передбачає застосування моделей представлення знань, які фактично мають бути покладені в основу іiі структурування [5]. Великого значення набуває також розробка автоматизованих систем, здатних проводити гнучке оцінювання навчальних досягнень, враховуючи велику кількість факторів, які не мають конкретного числового значення, а виражаються словами природної мови [6]. Важливою є також адекватна і гнучка інтерпретація одержаних результатів педагогічних вимірювань, яка дозволяла б зробити якісні висновки щодо напрямів коригування навчального процесу, максимально враховуючи індивідуальні потреби та особливості тих, хто навчається.

Все це актуалізує завдання пошуку дієвих інструментів та математичного апарату, здатних оптимізувати педагогічне діагностування та зробити його більш ефективним щодо підвищення якості навчальновиховного процесу. Кроком до розв'язання цих та інших проблем може стати застосування методів, підходів та засобів, які лежать у руслі такої галузі інформатики як штучний інтелект (ШІ) та з успіхом використовуються у його системах. Разом із цим одразу ж постає завдання удосконалення професійної підготовки педагогічних кадрів, пов'язане із опануванням відповідних інструментів штучного інтелекту та забезпечення їх ефективного застосування майбутніми фахівцями у галузі педагогічної діагностики. Отже, метою даної роботи є висвітлення основного кола проблем педагогічної діагностики, виокремлення на основі їх аналізу напрямів штучного інтелекту, найбільш перспективних щодо розв'язання цих проблем, а також формування дидактичних засад підготовки студентів педагогічних спеціальностей до розробки та експлуатації автоматизованих систем педагогічної діагностики.

\section{3. Літературний огляд}

Схарактеризуємо коротко предметну галузь Ш 3 метою виокремлення тих ії засад, які $є$ перспективними щодо їх застосування у руслі проблематики педагогічної діагностики. Зауважимо, що Ш як галузь інформатики зосереджується на проблемах ефективного моделювання процесу мислення людини. У спеціальних джерелах, зокрема у [7-10], відзначається, що із самого початку досліджень у цій області (кінець 40-х років 20го сторіччя) виділилися два доволі незалежні підходи до моделювання процесу мислення (логічний й нейро- кібернетичний), які втілюються у різних напрямах досліджень ШІ. Основними серед них вважають такі напрями $[7,8,10]$ :

- подання знань, що передбачає створення спеціалізованих моделей подання та методи обробки як чітких так і нечітких знань в комп'ютері, а також розробку апаратних та програмних засобів для їхнього перетворення;

- спілкування людини з комп'ютером, що включає завдання реалізації мовних засобів для ефективної взаємодії користувача з машиною, дослідження в галузі синтаксису і семантики природних мов, пошук способів збереження знань про мову в пам'яті комп'ютера i побудови спеціальних програм для перекладу текстової інформації у внутрішнє машинне подання;

- розпізнавання образів - напрям, що зосереджується на дослідженнях зі сприйняття зорової, слухової та інших видів інформації, методів ії обробки, формування відповідних реакцій штучних систем на вПливи зовнішнього середовища і способів його адаптації шляхом навчання;

- планування доцільного поводження, що передбачає створення методів формування цілей i розв'язання задач планування дій виконувача, що функціонує у зовнішньому середовищі;

- прийняття рішень на основі нечіткої логіки, яка дозволяє формалізувати поняття і уявлення про реальний світ, значна частина яких $є$ нечіткими, тобто не підлягаючими однозначному віднесенню їх (або їх характеристик) до певної множини;

- інтелектуальний аналіз даних, який зосереджується на моделюванні поведінки людини, що розв'язує складні інтелектуальні задачі узагальнення, виявлення закономірностей, знаходження асоціацій тощо.

Аналіз наведених напрямів досліджень засвідчує, що ШІ як наука має значний потенціал та надає потужні інструменти щодо їхнього залучення для роботи над проблематикою педагогічної діагностики. Найбільш перспективними 3 них уявляються моделі та методи представлення знань як інструменти моделювання предметної області; апарат нечіткої логіки для шкалювання показників успішності учнів (студентів) та для забезпечення гнучкості діагностичних систем; інтелектуальний аналіз даних та інші.

\section{4. Застосування інструментів штучного інте-} лекту до розв'язання завдань педагогічної діагностики

Обгрунтуємо і конкретизуємо, для розв'язання яких саме завдань педагогічної діагностики доцільно залучати штучно-інтелектуальні інструменти, що сформувалися у межах найбільш перспективних напрямів цієї галузі та схарактеризуємо основні дидактичні засади підготовки студентів педагогічних спеціальностей до розробки та експлуатації автоматизованих систем педагогічної діагностики.

Слід зазначити, що поняття «знання», «предметна область», «представлення знань», «моделювання предметної області» належать понятійному полю як педагогічної діагностики і педагогіки взагалі, так i штучного інтелекту, хоча і досліджуються у цих областях $з$ різних ракурсів [11]. Евристичні моделі представ- 
лення знань, застосовані у системах штучного інтелекту (зокрема, семантичні мережі, фреймові моделі, продукційні правила), спеціально розроблялися 3 метою ефективного моделювання предметної області, необхідного для їх зберігання в експертних системах та використання для виведення нових знань. Здійснене нами дослідження дидактичних можливостей цих моделей дозволило розробити методику дидактичного аналізу навчальної дисципліни $[5,11]$. На основі такого аналізу здійснюється структуризація знань, які за своєю сутністю $є$ елементами навчальної дисципліни як основного засобу реалізації змісту освіти.

Також нами було запропоновано практичні прийоми структурування будь-якої навчальної дисципліни, що відбувається на основі застосування основних евристичних моделей представлення знань [11]. Вони охоплюють декілька кроків, спрямованих на виявлення об'єктів і понять предметної області, встановлення та аналіз зв'язків між ними, побудову ієрархії знань тощо.

При моделюванні семантичною мережею проведене структурування забезпечує однозначний зв'язок семантичних даних із навчальним матеріалом. Це дає можливості для управління навчальним процесом i процесом контролю знань і їх адаптації, адже в результаті ми одержуємо інформацію про поняття і їх місцезнаходження у навчальному матеріалі. Семантичні одиниці, що стосуються даного поняття, 3 легкістю встановлюються для кожного навчального фрагменту.

Ключовим моментом такого виду моделювання $€$ семантичний розбір навчального тексту. Сам процес формування семантичних даних відбувається шляхом осмисленого читання навчального тексту і виділення 3 нього понять та тез. До автоматизованих засобів моделювання предметної області семантичною мережею відноситься, зокрема, програма TextAnalyst, яка дозволяє автоматично побудувати семантичну мережу понять, визначити вагу кожного поняття, вагу зв'язків між поняттями. Побудована модель предметної області покладається в основу структури навчальної дисципліни.

Моделювання предметної області фреймами є найбільш природним для здійснення саме модульного структурування навчальних дисциплін із збереженням та розповсюдженням зв'язків між навчальними елементами дисципліни. Після попередньої структуризації навчального матеріалу необхідно здійснити такі процедури:

1) побудувати класифікаційну ієрархічну структуру, у вузлах якої задано фрейми-прототипи, кожний 3 яких відповідає певному модулю дисципліни;

2) розробити макет фреймової системи, що відповідає модульній структурі навчальної дисципліни (метою даної процедури є змістове наповнення побудованої на попередньому кроці структури фреймової системи, спираючись на результати попереднього аналізу дисципліни: виділення навчальних елементів у кожному модулі, встановлення зв'язків між навчальним елементами цього модуля, інших модулів, модулів інших навчальних дисциплін);

3) реалізувати розроблений макет засобами програмного середовища, придатного для обробки фреймів, та побудувати запити 3 метою виявлення зв'язків між навчальним елементами дисципліни.
Зазначені аналіз і структуризація на основі моделей представлення знань необхідні для розв'язання цілого класу завдань педагогічної діагностики. Зокрема, вони $є$ необхідними для побудови системи навчальних елементів та компетенцій, які мають бути сформовані у тих, хто навчається, в результаті вивчення матеріалу дисципліни та, відповідно, продіагностовані щодо їх сформованості. Результати означених аналізу i структуризації $\epsilon$ основою для побудови узгодженої структури навчальних дисциплін різних типів, визначення індивідуальної освітньої траєкторії об'єктів навчання, складання бази завдань для тестів та інших форм діагностування навчальних досягнень школярів i студентів і формування на їх основі оптимальних комплектів завдань.

Однією із найважливіших функцій педагогічної діагностики $є$ подальша корекція навчально-виховного процесу за іiі результатами. У цьому аспекті великого значення набуває підбір комплексу методів навчання, які б відповідали рівню навчальних досягнень кожного учня індивідуально. Зрозуміло, що для ефективної реалізації такого диференційованого навчання, по-перше, необхідні гнучкі інструменти якісної діагностики індивідуальних особливостей учнів та студентів. 3 іншого боку, вирішення проблеми адекватної класифікації учнів (студентів) за результатами їх діагностування надасть можливість якісного добору методів навчання i, як результат, якісної корекції процесу навчання. У цьому контексті виявляється плідним застосування апарату нечіткої логіки та інтелектуального аналізу даних. Наприклад, враховуючи динамічність та невизначеність як самого навчального процесу, так і конкретно навчальних ситуацій діагностичного характеру, можна розробити певну методику проектування та аналізу означених навчальних ситуацій $з$ використанням елементів нечіткої логіки. Метою такого проектування $\epsilon$ зменшення розбіжності мети та результатів діагностування як на рівні кожної ситуації, так і на рівні кінцевого результату.

Важливою діагностичною проблемою $є$ також розробка критеріїв гнучкого оцінювання різноманітних якостей учнів та студентів при проведенні педагогічних досліджень та експериментів. До таких якостей, які зазвичай підлягають оцінюванню, належать, зокрема, якості знань (глибина, гнучкість, оперативність тощо), а також різноманітні особистісні якості. Застосування нечіткої логіки надає можливість розробити шкалу вимірювання певних параметрів, що є показниками тієї чи іншої якості і зазвичай виражаються поняттями природної мови («середня глибина знань», «дуже активний учень», «висока пізнавальна активність», «недостатньо сформований рівень оперативності знань» тощо).

Так, нами запропоновано методику побудови шкали оцінювання якості знань на основі нечіткої логіки. Схарактеризуємо іiі стисло на прикладі гнучкості знань, уникаючи суто математичні деталі. Виходячи із характерних ознак гнучкості знань, визначених І. Я. Лернером, для іï вимірювання доцільно застосувати серію нетипових завдань, а також завдання, які вимагають розв'язання задачі кількома способами. Нехай за кожну правильно вирішену нетипову задачу та за кожний правильний спосіб вирішення задачі учень (студент) отримуватиме 1 бал. 
Спираючись на відомі постулати нечіткої логіки $[6,11]$, співставимо дидактичному показнику гнучкості знань лінгвістичну змінну «Гнучкість», що може приймати, наприклад, значення «висока», «середня», «низька», які складатимуть іiі терм-множину. Значення кожного терму будемо визначати за допомогою так званого коефіцієнта гнучкості KFlex, який розраховується за формулою:

$$
K_{\text {Flex }}=\frac{P}{N}
$$

де Р - реально одержана учнем (студентом) кількість балів за розв'язання нетипових задач та віднайдені різні способи розв'язання; N - максимально можлива кількість балів за правильне вирішення завдань, спрямованих на встановлення гнучкості знань.

Далі проводимо фазифікацію, відповідно до встановлених кроків, результатом чого буде побудова так званих функцій належності $\mu^{\text {гн }}$ висока, $\mu^{\text {гн }}$ середня, $\mu^{\text {гн }}$ низька відповідно для термів лінгвістичної змінної «гнучкість»:

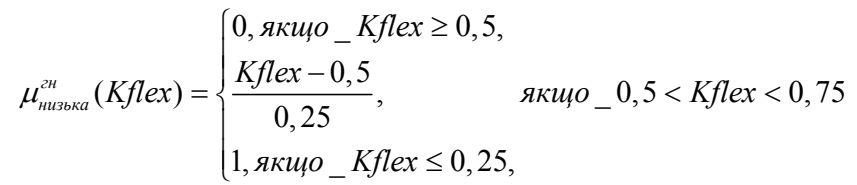

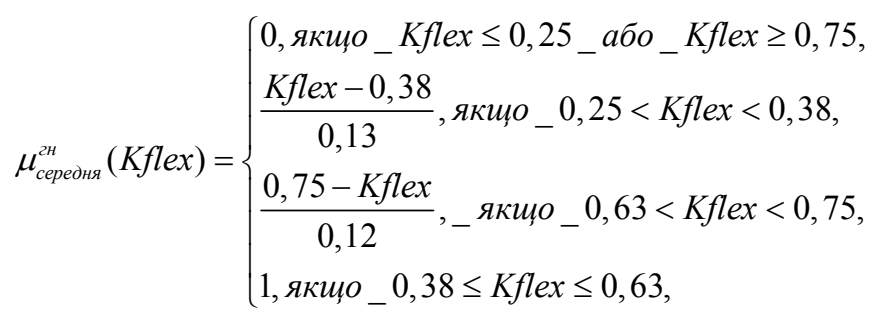

$$
\mu_{\text {висока }}^{\text {ги }}(\text { Kflex })=\left\{\begin{array}{l}
0, \text { якщоо_Kflex } \leq 0,5, \\
\frac{\text { Kflex }-0,5}{0,25} \\
1, \text { якщчо_Kflex } \geq 0,75,
\end{array} \text { якщзо_ } 0,5<\text { Kflex }<0,75,\right.
$$

Користуючись побудованими функціями належності, можна визначити ступінь належності будьякого значення коефіцієнта гнучкості KFlex до відповідних множин (висока, середня або низька гнучкість), а також здійснити процедуру обробки нечітких правил, що у свою чергу уможливить врахування оцінки гнучкості знань в індивідуальному профілі навчальних досягнень учня (студента). Аналогічно можна побудувати шкали для вимірювання та врахування інших якостей знань, спираючись на їхню дидактичну сутність.

На основі побудованих функцій належності нами було розроблено спеціальну комп'ютерну модель у середовищі пакету динамічної математики GeoGebra. Ця модель дозволяє шляхом зміни порогових значень побудувати оптимальні шкали для усіх термів кожної лінгвістичної змінної.

Зауважимо, що запропоноване шкалювання якостей учня (студента) дозволить накопичити якісні статистичні дані для ефективного та гнучкого оцінювання результатів педагогічних експериментів.
Іншим напрямом застосування апарату нечіткої логіки у педагогічній діагностиці $є$ побудова нечіткого дерева рішень. Застосування нечітких дерев рішень для моделювання систем зумовлено можливістю наочного представлення системи і легкістю інтерпретації причинно-наслідкових зв'язків між концептами. Завдяки застосуванню алгоритму побудови нечіткого дерева рішень стає можливим розв'язання діагностичних завдань такого типу. Припустимо, що необхідно прийняти рішення щодо залучення конкретної групи студентів до роботи у деякому науково-практичному проекті, спираючись на дані про такі атрибути: «уміння працювати в команді» та «інтегральна оцінка професійних якостей студента, які потрібні для роботи у проекті». На основі зібраних даних будується нечітке дерево рішень, за допомогою якого можна буде визначати ступінь приналежності студентів із різними професійними якостями та умінням працювати в команді до цільового класу тих, кого доцільно залучити до роботи у проекті, а також досліджувати вплив кожного 3 атрибутів на рейтинг студенту [11].

Частинною задачею інтелектуального аналізу даних є задача кластерного аналізу, методи, стратегії та результати якого можуть бути з успіхом застосовані у системах педагогічної діагностики для розв'язання іiі конкретних завдань. Зокрема, при використанні результатів діагностування виникає така задача. Існують результати вимірювань (спостережень) певної сукупності якостей студентів або мотивів їх поведінки, ставлення до предметів тощо. Необхідно студентів розбити на певні класи (кластери) за одержаними результатами вимірювань (спостережень). Таке розбиття уможливить навчання із застосуванням для студентів кожного кластеру відповідної групи методів для удосконалення та коригування навчально-виховного процесу. Для розв'язання цієї задачі доцільно застосувати кластерний аналіз, який шляхом виконання відповідних до обраного методу кластеризації кроків забезпечить побудову кластерної структури досліджуваної групи студентів. Конкретні прийоми здійснення деревоподібної кластризації задля педагогічної діагностики наведено у [11].

Проведене нами обгрунтування залучення означених штучно-інтелектуальних інструментів до конкретних завдань педагогічної діагностики уможливлює формування відповідного дидактичного забезпечення фахової підготовки педагогічних працівників до здійснення діагностичних заходів, а також до розробки та експлуатації систем педагогічної діагностики. Так, 3 метою висвітлення необхідних теоретичних основ окреслених штучно-інтелектуальних напрямів та інструментів автором підготовлено до друку навчальний посібник «Штучний інтелект і його застосування у системах педагогічної діагностики» [11], що охоплює шість розділів з указаної теми. У ньому розглядаються напрями та інструменти штучного інтелекту, які можуть бути застосовані у системах педагогічної діагностики для вирішення іiі основних проблем, надаються приклади та конкретні прийоми використання штучноінтелектуальних засад у галузі педагогічної діагностики. Крім теоретичних відомостей у посібник включено контрольні запитання та практичні завдання, які можуть стати основою для дидактичного забезпечення 
лабораторного практикуму з означеного навчального курсу для студентів педагогічного університету.

Крім цього нами збагачено навчальний курс «Основи штучного інтелекту», який викладається магістрантам спеціальності «Інформатика» ХНПУ імені Г. С. Сковороди, відповідною серією практичних та навчально-дослідних завдань. Так, крім знайомства із загальними положеннями нечіткої логіки, магістрантам пропонується, наприклад, визначити лінгвістичні змінні, що відповідають певній якості знань, їх терммножини та функції належності кожного терму, дослідити поведінку цих функцій належності і визначити «границі чутливості» шкал. Таке нечітке моделювання студентам рекомендується здійснювати у середовищі MATLAB, в якому передбачений спеціальний інструмент Fuzzy Logic Toolbox.

Інша серія завдань містить вправи на побудову дерева нечітких рішень щодо віднесення того, хто навчається, до певного класу за результатами моніторингу його навчальних та особистісних досягнень. Апробування своїх наробок, одержаних у межах курсу, магістрантам пропонується здійснити під час дослідницької практики.

Індивідуальні навчально-дослідницькі завдання до курсу передбачають побудову комплекту тестових завдань до окремих навчальних дисциплін на основі застосування моделей представлення знань.

Отже, пропоноване дидактичне забезпечення дозволить сформувати у майбутніх фахівців систему знань і умінь 3 основ штучного інтелекту, необхідних для ефективного розв'язання завдань педагогічної діагностики, а також базованих на конкретних практичних прийомах застосування штучно-інтелектуальних засад у цій галузі.

\section{5. Апробація результатів досліджень}

Одержані у ході роботи результати знаходять своє використання у межах професійної підготовки студентів спеціальності «Інформатика» фізикоматематичного факультету ХНПУ імені Г. С. Сковороди та спеціальності «Соціальна інформатика» факультету СУЛА НАУ імені М. С. Жуковського «ХАІ». Відповідно до довідки, впровадження матеріалів роботи у навчальний процес має позитивні наслідки. Окремі наробки застосовуються у ХНПУ імені Г. С. Сковороди у межах науково-дослідної роботи за темою «Розробка науково-теоретичних i технологічних засад побудови автоматизованої системи педагогічної діагностики в навчальному закладі».

\section{6. Висновки}

В роботі висвітлено сутність, функції та основні проблеми педагогічної діагностики. На основі їх аналізу виокремлено найбільш перспективні напрями штучного інтелекту, які мають певний потенціал щодо розв'язання нагальних завдань педагогічної діагностики (моделі та методи представлення знань як інструменти моделювання предметної області; апарат нечіткої логіки для шкалювання показників успішності учнів (студентів) та для забезпечення гнучкості діагностичних систем; інтелектуальний аналіз даних). Конкретизовано відповідні штучно-інтелектуальні інструменти, наведено прийоми їх залучення до розв'язання завдань педагогічної діагностики. Схарактеризовано необхідне дидактичне забезпечення фахової підготовки студентів до здійснення діагностичних заходів, а також до розробки та експлуатації автоматизованих систем педагогічної діагностики із залученням інструментів штучного інтелекту.

\section{Література}

1. Гаврилов, А. В. Системы искусственного интеллекта [Текст] / А. В. Гаврилов. - Новосибирск: НГТУ, 2001. $-246 \mathrm{c}$.

2. Гарбусєв, В. Основи тестових технологій [Текст]/ В. Гарбусєв // Інформатика. - 2007. - № 16 (400). - С. 3-22.

3. Гризун, Л. Е. Дидактичні основи проектування модульної структури навчальної дисципліни на засадах інтеграції наукових знань [Текст]: дис. ... доктора пед. наук : 13.00 .04 / Л. Е. Гризун- Харків, 2009.-417 с.

4. Гризун, Л. Е. Напрями застосування апарата нечіткої логіки для розв'язання завдань педагогічної діагностики [Електронний ресурс] / Л. Е. Гризун // Народна освіта : зб. наук. пр. - 2014. - Вип. 1 (22). - Режим доступу : http://narodnaosvita.kiev.ua/?page_id $=2165$

5. Гризун, Л. Е. Штучний інтелект і його застосування у системах педагогічної діагностики [Текст] / Л. Е. Гризун. - Х. : ХНПУ імені Г. С. Сковороди, 2014. - 151 с.

6. Колгатін, О. Г. Дидактичні вимоги до засобів автоматизованої педагогічної діагностики [Текст] / О. Г. Колгатін // Засоби навчальної та науково-дослідної роботи : збірник наук. праць / ХНПУ імені Г. С. Сковороди. - 2007. Вип. 27. - С. $65-74$

7. Максимов, В. Г. Педагогическая диагностика в школе [Текст] / В. Г. Максимов - М.: Академия, 2002. -270 с.

8. Подласый, И. П. Педагогика: Новий курс. В 2 кн. [Текст] / И. П. Подласый. - М. : Гуманит. изд. центр ВЛАДОС, 2002. $-576 \mathrm{c}$.

9. Поспелов, Г. С. Исскуственный интеллект - основа новой информационной технологии [Текст] / Г. С. Поспелов. - М.: Наука, 1989. - 280 с.

10. Представление и использование знаний [Текст]/ пер. с япон. под ред. Х.Уэно, М. Исидзука. -М. : Мир, 1989. - 220c

11. Субботін, С. О. Подання і обробка знань у системах штучного інтелекту та системах прийняття рішень: Навчальний посібник [Текст] / С. О. Субботін. - Запоріжжя : ЗНТУ, 2008. - $341 \mathrm{c}$.

\section{References}

1. Gavrilov, A. V. (2001). Systems of artificial intelligence. Novosibirsk: NGTU, 246.

2. Garbusev, V. (2007). Basics of Test Technologies. Informatics. Apr, 16 (400), 3-22.

3. Gryzun, L. E. (2009). Didactic bases of projecting of the subject modular structure on the basis of scientific knowledge integration. Kharkiv National Pedagogical University named after G.S. Scovoroda, 417.

4. Gryzun, L. (2014). Ways of fuzzy logic application to the solving problems of pedagogical diagnostics. Narodna Osvita, 1 (22). Available at: http://narodnaosvita.kiev.ua/?page_id=2165

5. Gryzun, L. E. (2014). Artificial Intelligence and its application to the systems of pedagogical diagnostics. Kharkiv : KhNPU named after G.S. Scovoroda, 151.

6. Kolgatin, O. G. (2007). Didactic requirements to the means of automatic pedagogical diagnostics. Means of teaching and scientific-research work. Kharkiv : KhNPU named after G.S. Scovoroda, 27, 65-74.

7. Maksimov, V. G. (2002). Pedagogical diagnostics at school. Moscow:Akademiya, 270.

8. Podlasyy, I. P. (2002). Pedagogy. New Course. Moscow : VLADOS, 576. 
9. Pospelov, G. S. (1989). Artificial Intelligence is a base for new information technology. Moscow : Nauka, 280.

10. Knowledge representation and application. (1989). Transled from Japanese by H. Ueno, M. Isidzuka.
Moscow : Mir, 220.

11. Subbotin, S. O. (2008). Knowledge representation and processing in the systems of artificial intelligence and decision-making systems: Textbook. Zaporizhia: ZNTU, 341.

Дата надходження рукопису 25.12.2014

Гризун Людмила Едуардівна, доктор педагогічних наук, професор, кафедра інформатики, Харківський національний педагогічний університет імені Г. С. Сковороди, вул. Артема, 29, м. Харків, Україна, 61078 E-mail: Lgr2007@ukr.net

\section{УДК 004.89}

DOI: 10.15587/2313-8416.2015.36743

\section{СТОПРОЦЕНТНЫЙ УЧИТЕЛЬ}

\section{(C) Т. А. Пушкарева}

В статье рассматриваются особенности решения вопросов компьютеризации, информатизации образования и 100 \% ликвидаџии компьютерной безграмотности, а так же подготовки и повыщения квалификации педагогов в рамках государственной иелевой программы "Сто проиентов". Раскрыты возможности дистанционного обучения, роль учителя в этом процессе и требования к педагогической деятельности в новых условиях

Ключевые слова: информатизация, компьютеризация, дистаниионное обучение, электронные образовательные ресурсы, электронная образовательная сеть, информационно-коммуникаиионная среда

In the article discusses the features resolution such questions as computerization, an education informatization and $100 \%$ elimination of computer illiteracy and also training and professional development of teachers in the framework of state program "One hundred percent." The possibilities of distance learning and teacher's role in this process are revealed as well as requirements for towards teacher's pedagogic activity in new conditions

Keywords: informatization, computerization, distance learning, e-learning resources, e-education network, information and communication environment

\section{1. Введение}

Какого учителя сегодня, в обществе глобальной информатизации, всеобъемлющего влияния сетевых интернет технологий на умы и души наших детей, можно назвать - «стопроцентный учитель»?

Видимо только такого, который является высококомпетентным в сфере ИКТ (информационнокоммуникационных технологий), профессионально не только владеет, но и эффективно применяет информационные технологии в своей педагогической практике.

Стандарты ИКТ компетентностей, разработанные ЮНЕСКО, хорошо известны современной педагогической общественности.

\section{2. Анализ литературных данных и постановка} проблемы

В частности учителя, которые овладеют навыками пользователей ПК, как минимум, должны уметь создавать текстовые документы, таблицы, рисунки, диаграммы, презентации; использовать локальные сети и базы данных; осуществлять анкетирование, диагностирование, тестирование, а также разрабатывать собственные электронные продукты (разработки уроков, демонстрационные материалы и использовать готовые электронные продукты в своей профессиональной деятельности [1-8].

Но какова сегодня реальная картина с компьютерной грамотностью у украинского учителя?
Еще недавно, до 2011 года показатель владения учителями компьютером колебался от 30 до 50 \% среди регионов Украины. Эта ситуация осложнялась тем, что среди учащихся этот показатель был значительно выше. Эта, как и многие другие проблемы информатизации общества требовали быстрого и эффективного решения.

С целью стимулирования инновационного развития образования, повышения его качества, Указом Президента Украины от 30 сентября 2010 г. № 926 2011 год был объявлен Годом образования и информационного общества в Украине [9].

Среди целого ряда важнейших инициатив по реализации Указа Президента особое внимание было уделено Государственной целевой программе внедрения в учебно-воспитательный процесс общеобразовательных учебных заведений информационнокоммуникационных технологий «Сто процентов» $[2,6]$. Программа фактически взяла на себя решение всех накопившихся проблем компьютеризации, информатизации образования и 100 \% ликвидации компьютерной безграмотности среди педагогов.

\section{3. Формулировка цели статьи}

В статье определена роль компьютерной грамотности как составляющей подготовки учителей в свете требований современного мира. Повышение компьютерной грамотности учителей - одно из первооче- 